\section{AN ADQRESS}

\author{
os
}

\section{THE REVIVAL OF OVARIOTOMY, AND ITS INFLUENCE ON MODERN SURGERY.}

Detivered at the opening of the Midland Medioal Society; at Birmingham, November 5th, 1884.

By Sir SPENCER WELLS, BarT., Late President of the Royal College of Sturgeons of England.

Mr. President and Gentlemen, Members of the Midland Medical Societr, - Next to the satisfaction which attends the fulfilment of the first duty of our calling-the relief of suffering and the prolongation of human life, which the Roman orator said raised the giver of health to man nearer to the Divine Giver of life-I know of no higher privilege than that of being permitted to address educated minds, of endeavouring to influence for good, medical thought, and opinion, and practice-whether by the aid of the art of the printerthat " magic which embalms the thought"-or by addressing such an assemblage as this, with the knowledge that what may be said before you (after as much careful preparation as the too scanty leisure of a very active life permits) will be carried as far as our language is read or translated. The honourable privilege, as rare as it is enviable, of addressing a great gathering of fellow-workmen, of corresponding pursuits and tastes, from whom one may confidently expect a sympathetic hearing and active response, can hardly be overestimated. Much or little as we may know of each other, we are all united by the strong tie of professional interest ; by the ambition to do well our daily work, and, I hope', by the desire so to make use of the meeting as. to fuse temporary contact into durable friendship. I know that I see before me an assembly of no average intellectual standard. In days gone by, in this favoured district of our fatherland, there were "mighty men which were of old, men of renown"-the generations who have helped to make Birmingham what it is - the Areopagus of the Midlands. So to-day, the men who still kindle its enthusiasm, still direct its energies, and are the master-spirits of its industry, its patriotism, its loyalty, are aided and influenced by a residential doctorate equal to the task of keeping such a population sound in body, sound in mind, and of thus economising the vast financial interests depending on its sanitary condition. The members of this Society now take the place, as a protective educational power, which was formerly filled almost entirely by the priest. Perhaps, in many cases, you do for the bodily health what is done by the rector or the nonconformist teacher for the moral direction of the parish. You are ready and willing to fulfil your high vocation, guiding your course of action as a beneficent irrigating stream, in the midst of a people whose bodily and mental welfare is entrusted to your charge.

What to say to such an audience is, of course, the first question. Of local affairs you know more than I do. Medical politics and controversial topics must be avoided. I have been told that yon would probably be disappointed if I did not tell you something more of my own work, of what I have done and how I did it, why I did it, of my successes and my failures, how mistakes have become less frequent and progress more certain, than can be learnt from anything $I$ have yet published. Acting on this hint, and knowing that in the minds of many of you my name is more closely associated with the practice of ovariotomy than with any other surgical question, I would first ask your attention to one phase in the history of the development of the operation, that which has been well termed the "revival of ovariotomy in England."

There are not many here who can carry back their reminiscences so far as mine go. Without being formally apprenticed, I had all the advantages of the old apprenticeship-system, under an unusually able and worthy man, the late Michael Thomas Sadler, of Barnsley in Yorkshire. For one year I lived with one of the parish surgeons of Leeds, attended the lectures of Hey and Teale, and saw much practice in the Leeds Infirmary. In 1837-38. I was in Dublin, under Graves and Stokes, Crampton, Beatty, Harrison, Apjohn; and Jacob. In 1839-40 I worked hard in St. Thomas's Hospital under Green, Travers, and Tyrrell. I obtained the prize for the fullest reports of examinations of the bodies of patients dying in the hospital during that period. But neither in the dead-house, nor in the wards or otit[1245] patient room of St. Thomas's, nor in Dublin, nor in Leeds, nor during my pupilage, carr I remember eper having once seen a case of ovarian disease. I never heard a lecture upon the subject. Very little was said about it in any of the text-books, and the way in.which it was introduced showed that it was. not thought of sufficient importance for the attention of students to be drawn to it.

I very much doubt whether it ever formed any part of the examination at either the College or the Hall. We now know that, though Morgan, Key, and Bransby Cooper at Guy's Hospital, in 1839 and 1840, and Phillips at the Marylebone. Workhouse in 1840 each operated once, the matter was not in any way brought under the notice of the medical students of that time. I have no doubt that the operations at Guy's were done under the influence of Blundell, who had been professor of obstetrical medicine in that hospital. In the edition of his Obstetrical Medicine, published in 1840, there is a chapter on ovarian dropsy very far in advance of the general knowledge of the day. To illustrate the routine treatment of the disease, he relates a characteristic saying of Abernethy, who, consulted on a case where tapping was useless, on account of the viscid character of the contents of an ovarian cyst, said, "It won't do to go on boring holes in the belly." Probably Sir Astley Cooper's famous story of a case of "dry tapping" may be explained in the same way.

But I had not seen Blundell's book, and it was not till many years afterwards that I even heard of the name of McDowell, or of any of the fourteen cases of ovariotomy done in Great Britain between 1825 and 1839 . It was not until I had myself written on the subject that I learnt that William and John Hunter had thought of and sug. gested the operation, or that John Bell had so lectured as to inspire McDowell with the determination to do what he afterwards did. In fact, I believe that most teachers and students of that day knew as little or cared as little about the subject as I did.

Very soon after becoming a member of the College of Surgeons in 1841, I entered the Royal Navy as Assistant-Surgeon, and for about six years served in the Naval Hospital at Malta. In addition to naval practice, I saw many patients, both male and female, and did many operations, in consultation with resident practitioners in Malta. But I cap only recollect one case which, I now believe, might probably have been a case of ovarian tumour, but which at that time was a puzzle to us. My old friend Dr. Waters, of Chester, has lately reminded me that he and I had conversed on the subject of ovariotomy in Paris in 1848. But he spoke with knowledge acquired in Edin. burgh under Hughes Bennett-I in complete ignorance. Still, it is curious that we both came to the conclusion that, upon the facts as they then stood, ovariotomy was not a justifiable operation.

It was not until after settling in practice in London, which I did in 1853, that I ever saw a patient whom I knew to be suffering from ovarian disease. In $1854 \mathrm{I}$ joined the Samaritan Hospital, at that time a dispensary for the diseases of women-a subject of which I knew less than of any other special division of our profession. In my young days I had done an unusual amount of midwifery, but latterly my practice had been almost exclusively surgical, with a strong tendency towards ophthalmic surgery. In 1853 or 1854 , I became acquainted with Baker Brown. He occasionally came to the Samaritan Hospital, which he wished to join, and I two or three times saw patients with him at St. Mary's Hospital. In April, 1854, I and my friend Nunn, of the Middlesex Hospital, assisted Baker Brown in his eighth case of ovariotomy. This was the first time I had ever seen the operation attempted; and it certainly did not encourage me to look favourably upon ovariotomy. The patient died, and her death discouraged Brown. He, Nunn, and I, talked the matter over, and I well remember Brown's saying, "It's the peritonitis that beats us." His first three cases died, the fourth recovered, his fifth and sixth died, the serenth recovered, and the death of the eighth, in 1854 , and of the ninth, in 1856, led him to cease operating for more than two years and a half, and again to advocate treatment by pressure and iodine. He did not perform ovariotomy between March, 1856, and October, 1858.

When the Crimean War broke out, I left London, served with the army in the East, and of course lost sight for a time of all the diseases of women. Any impression that I had received as to ovariotomy was certainly not favourable; but I did see cases of abdominal wounds which taught me that the peritoneum would bear much rougler handling than I had previously believed permissible. I had written about hernia, and had advocated division of the stricture without opening the sac whenever possible, simply to avoid the danger of admitting air or blood into the peritoneal cavity. But I learnt in the Crimea that a man's abdominal wall might be lacerated by fragments of shell, his intestines protruding and covered with mud, so remaining. for soveral hours; and yet that, after careful cleansing of the cavity and 


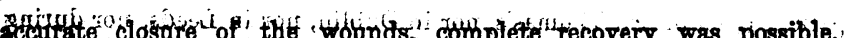
When I téturned to London; in $185, \mathrm{\theta}$, was certainly much less afraid than before of abdominal wounds. I took up my work at the Samaritan Hospital agdin, but at first saw very few cases of ovarian disease. The first made a very painful impression apon me. Snow Beck tapped a very fine young woman, and injected iodine, he thought into the cyst; bat he really injected the peritoneal cavity. He had toot taken the precaution of passing a long catheter through the short cannula of his trocar; the etnptied cyst slipped off the cannula, and several ounces of tincture of iodine passed diretly into the peritoneal carity. Beck was greviously distressed; but the case did not so much deter us from the use of iodine as awaken us'to the necessary precautions as to the mode of injection. But we had very few cases of ovarian disease, and it was not till December, '1857, that I made my' first attempt to perform ofarlotomy. A tolerably full report of the case was published at'the time, atrd reprinted in 1865. Baker Brown was present, and strongly dissuaded me from going on with the operation, on the ground that, as the tumour was behind the intestimes, it could not be ovarian.

It is not easy to estimate correctly the part played by Baker Brown in the progress of gynæcology. In the minds of many, his really great services have been overshadowed by the errors of this later practice. Some, who fully acknowledge and admire what he did to popularise the operations for the cure of raptured peringum and resicovaginal flstula, and who now recognise the' great success which at tended his adoption afterwards of John Clay's suggestion of 'dividing the pedicle of an ovarian tumour by' the combined action of strong compression, or crushing with the actual cautery, forget, or never krew; that when Brown assisted me in the case which $F$ have just re ferred to, and in another which I am about to mention, his own early experience of ovariotomy 'had' led him rather to oppose than encourage the repetition of the operation. At my second attempt, my first case of completed ovariotomy, Brown again assisted mo; and in my first, and in all subsequent reports of the operation; I have fully acknowledged his zealous assistance. But it was not until after I had had three successful cases that Brown himself began to operate again, after an interval of more than two years and a half. At this third case Tyler Smith was present." He was greatly surprised at the successful result, and it induced him not only to cease the opposition he had formerly offered to Brown's practice, but to operate himself, which he did with greàt success.

I think it would be difficult to rmagine a position more disheartening than that in' which I was placed' when making my first trials of ovariotomy. The first attempt, ${ }^{\text {as }} \mathrm{I}$ hate said, was a complete failure, and strengthened, not only in the minds of others, but in my own mind, the fear that I might be entering upon a path which would lead rather to an unenviable notoriety than to a sound professional reputation. And if I had not seen increasing numbers of poor women hopelessly suffering, almost longing for death, anxious for relief at any risk, I should probably have acquiesced in the general conviction -have been content with palliative tapping, or making some further trials of incision and drainage, or of iodine-injection, or of pressure, rather than have hazarded anything more in the. way of ovariotomy. It may be forgotten now, but it is true, that at that time everything was against the venture. The medical press had denounced the opera'tion, both in principle and practice, in the strongest terms. At the medical societles, the speakers of the highest authority had condemned it most emphatically. The example of the men who had practised it was not followed; some of them had given it up. Only once had a successful result been obtained in any of our large metropalitan hospitals, that by Cæsar Hawkins, at St. George's Hospital, in 1846 and he never undertook it a second time. Every other attempt, at Guy's Hospital 'by Morgan, Key,' and Bransby. Cooper, at St. Thomas's iy Solly, had ended in death.

This was how we stood at the end of 1857. It was in February, 1858 , that I completed the operation for the first time. I need say no more about it now than that it led to my being congratulated by Dr. West upon "complete success," and, with other evidence, to his thorough conversion from his previous condition of conscientious and determined opposition to a state of warm stipport, both in public and private. Let me read to you part of a letter written by my friend Keith of Edinburgh. In the BRITISH MEDICAL JourNal, in 1873 , Keith wrote : "Few watched more eagerly than I did the history of this operation, and few know so well the details of the early cases. Till 1858 I could find nothing whatever anywhere to encourage, but everything to deter "one from attempting it. Ovariotomy: was then, as an operation, simply nowhere ; and had the practice of using Dr. Clay's long intrapefitorieal ligatures been continued, it would have yet been" nowhere." "Up till that year, Mr. Brown had lost seven out of his nine patients, and had ceased operating for upwards of two years and a half. Surely there was nothing for iny one to learn from such results, except, perhaps, what there might be to avoid." Keith was one of the first to follow me, and did more than anyone else at that time to assist in the reviral of ovatiotomy. I had done: eight cases when he began; and over since we have gone on side by side, very friendly rivals' assisting each other, eomparing notes, -not always running on the same track, but always equally anxious to perfect the operation. You all know how w.onderful his success has been. Some of his later cases of the removal of uterine tumours are unsurpassed as surgical achievements. He concludes the letter; part of which I just read, by asserting, as others, both before and since; home and abroad, have also done, and which it is my highest pride and pleasure. to feel was not due only to their friendly feelings; - but brecause it is true, that the period of progress, ".the revival of evariatamy"? began when the results of my earlier operations were made known $f$ ! and. the confidence of the profession was obtained by the publication of every case, whether successful or not.

Anyone who will look over the reports of my early cases, who will see the names of the men who sent me the patients-West, Rigby, Watson, Acland, Hare, Stokes, and Oldham-of those who, as well as my colleagues, Savage, Priestley, Graily Hewitt, assisted me, on were present at the operations, among whom I may mention Paget, Fergusson, Tyler Smith, Bowman, Seymour.Haden, Pirrie, Baker, Grimsdale, Bickersteth-who discussed with me various questions which arose as to pathology and treatment, Aitken, Richardson, Ritchie, Hutchinson, Frank; Druitt, Robert Lee, Churchill, Beatty, and Simpson-who, for their personal assurance, like Nélaton; Worms, Demarquay, Gueneau de Mussy, Péan, Courty, came from ..France; or De Roubaix and Boddaert from Belgium; or from Germany, as Schuh, Billroth, Esmarch ; from Italy; as Porta, Vanzetti ; or from America, as Gross and Marion Sims-will find no difficulty in understanding that we had how reached a turning-point. Some of these timely allies have finished their course. Some remoin ripened and matured by years of experience-not yet worn out, but finding their greatest. happiness in their daily work, and in friendly association with their fellows and jumiors. When I can name such men as not only having witnessed and sanctioned the operation, but as becoming convinged, $\mathrm{hy}$ following up the cases, that it was at least as successful is iother serious operative proceedings, and when I add that mapy of these men soon began; to perform the operation themselves, and publialy to advocate it-no one, I say, who considers all this, will be surprised at the rapid rise and progress, of ovariotomy between 1858 , when it was revived, and 1864, when it was very generally accepted as a legitimate operation, and was not long afterwards cited as a triumph of modern surgery.

If I were to select from the books and pamphlets (most of which I have carefully preserved) published during these six years, any one work which contributed more than others to form professional opinion to awaken interest, and to instruct those who had before not thought upon the subject, it would be the tables of cases most industriously collected by your own townsman, John Clay, and published as an appendix to his translation of Kiwisch's Clinical Lectures on Diseases. of the Ovaries. The tables are now of far more value than the lectures. One of Clay's chief merits is the example he set of obtaining all the information possible as to every recorded case of ovariatomy, completed or attempted, from the first up to 1860 ... He collected such a mass of facts, and arranged them for reference or study so conveniently, that he supplied us with fuller and more trustworthy information than had ever before been gathered together apon, any surgical question; and I think he may be said to have done more than helped in starting what is now called the "collective. investigation of disease."

From these tables, as arranged by Clay, and from a perusal of the works published about that time, we can now see how fully the principles and many of the practical details concerned in the matter had been discussed. What may be called the ethical or moral side of the question had been fully argued. The fears and forebodings as to the physical and physiological effects of the removal of an ovarysuch as the abnormal accumulation of fat, the devalopment of masculine type, and the restriction of the sex of infants-were dispelled and falsified. The causes of death in fatal cases had been investigated. Many of the mistakes of the earlier operators had been corrected ; and, far above all other things, the profession had gained confidence in the accuracy and completeness of the facts laid before them. The old plan of operating in a hot moist chamber, and keeping the room overheated for days afterwards, was soon abandoned. The semi-recumbent position of the patient was exchanged with great advantage for the horizontal. Safer anæsthetics than chloroform were usod. Simple 
bandages for keeping the patient quiet supplied the place of an objectionable crowd of assistants. Precautions, never before thought much about, were taken for protecting the patient from any infectious disease; by obliging every visitor intending to be present to declare that he had not made a post mortern examination, nor been into a dissecting-room, nor attended any case of infectious diseaso within a woek; by the utmost attainable purification of the house, room, belding and clothing, sponges and instruments-in fact, of everything brought near the patient; and all this was was insisted on with a pertinacity which often gave offence. A great deal was gained by shortening the incision in the abdominal wall, by emptying the cyst before drawing it out, or by lessening the bulk by breaking down the septa of multilocular cysts; by extreme care in preventing the entrance of ovarian fluid into the peritoncal cavity, or by very carefully cleansing the cavity from any blood or fluid which had entered it -a process christened by Worms the " toilet of the peritoneum." Sir Benjamin Brodie long ago remarked, with regard to lithotrity, that suecess depended upon attention to a number of minute details. So with ovariotomy. No onc of the details to which I have just alluded may be alone of any great importance; but, taken together, they did a great deal towards preventing failure and securing success. Other modifications of more or less importance were soon made. The old vegetable material for ligatures and sutnres, coarse whipeord or twine, was ahandoned. After many trials of silver, iron, or platinum-wire, horsehair, fish-gut, and other materials, we settled upon pure silk as the most useful and trustworthy, and proved that, after a few weeks' retention in the animal body, it entireiy disappeared. The mode or process of its removal by the insinuation of white blood-corpuscles between its fibres, a sort of untwisting or solution, was watched stage by stage; and long before the treatiment of the pedicle in this manner was seriously proposed, we learnt that silk ligatures, and portions of omentum secured by them, might safely be left within the abdominal cavity. Nathan Smith was the first to treat the pedicle in this way, but he made his ligatures from a leather glove. Tyler Smith was the first to revive the practice, using silk. $A$ story has been very generally believed-probably some of you may have heard it-that Tyler Smith's first trial was accidental; that he cut off the ends of the ligatures inadvertently, forgot all about them, and ras surprised to find that his patient recoverel. But on inquiring of his former assistant, Dr. Edwards, who is still in practice in London, I am assured that there is no ground for this story. The operation was performed in June, 1861. Dr. Edwards writes : "Previously to this operation, I had strongly advocated the advisability of dropping the pedicle and cutting short the ligature, and it was at my initiation that it was done. In fact, I did it myself."

The mode of treating the pedicle became a subject of anxious discussion. The evils which attended the use of the long ligatures were soon found to outweigh any advantage obtained by their service in drainage. The extraperitoneal method was simplified by Hutchinson's introduction of the clamp, and for a long time it was only in cases where the clamp could not be used that any other method was sought for. 1 had hoped much from the ecraseur, but used it once only. Others had spoken of crushing the pedicle and twisting off the cyst. I had an instrument made for tearing through it-a rough bluntish saw. But all these plans, without much trial, gave way before that combination of crushing and cauterising for which surgery will be for all time indelted to your own Clay. Ûsed at first by him for dividing omentum, both he and I suggested that this might be a good mode of dividing the pedicle in ovariotomy. Baker Browu was the first to carry out this suggestion in practice, and with immediate improvement in the results he obtained. Keith followed him, and, with occasional intermissions, has continued the practice. I also had very good results in thirty cases, and have sometimes blamed myself for not having given it a more extensive trial. I did not give it up, how. ever, until I thought I had proved the ligature to be more trustworthy in cases of short pedicle. What is called the complete intraperitoneal ligature-by which wc mean the transfixion of the pedicle, tying it in two or more portions, cutting off the ends of the silk close to the knots, and returning them with the tied stump after cutting off the cyst-was by no means a common practice until long after the date of which I have been speaking.

The mode of closing the opening in the ahdominal wall was one of the first things to attract my attention, and no one before me seems to have cared whether the peritoneum was included in the sutures or not. A very few still maintain that it is a matter of no consequence, and Koberlé still asserts that it is better not to include it. I have not time now to trouble you with a thrice told tale of how, by examination of patients who died after ovariotomy, and by experiments on animals, I convinced myself that, by passing the sutures through the whole thickness of the abdominal wall, including the peritoneum, at such a distance from the divided edges as to permit two surfaces of the scrous membrane being brought into contact when the sutures wcre tied, instead of merely bringing the edges together, a more permanent and complete union was obtained, and that one source of inmediate danger was avoided-I mean the oozing into the abdominal cavity of blood, or serum, or fat, from the divided tissues. So, too, we got rid of the inconvenience which patients who recorer sometimes suffered, from the adhesion of omentum or intestine to the abdominsl wall.

I need not say much about the mode of dressing the wound, but I think it is of some importance to note that from the first I was very careful to keep the wound as dry as possible. I had became convinced in my neval and military practice that water-dressing and other moist applications (without going into any discussions as to the cause of pyamia) were far inferior to dry dressing. For several years I used pads containing Skinner's mixture of calcined oyster-shells and oil of tar, covered with layers of cotton-wool, and supported by the gentle pressure of a flannel bandage; and the only modification, made of late years, in these dry dressings, has been the substitution of the elegant and comfortable pads devised by your townsman, Gamgee, for the antiseptic and absorbent nowder of Skinner.

The chief improvement made in the after-treatment was in greatly diminishing the amount of opium. Large doses had often injured the patients, and, I thought, might have been the cause of death in some of the earlicr cases.

By careful considerntion of all the sources of danger, and by successive improvements in practical details, the mortality of ovariotomy became less excessive; and it was soon felt that the mortality after other surgical operations, both in London and provincial hospitals, as well as in private practice, rras excessive, and ought to be diminished. It was some years after Southwood Smith, Edwin Chadwick, and Wil. liam Farr had begun their attempt to impress the importance of a knowledge of sanitary science upon the people of England, that its influence was much felt, either in hospital-practice or in domestic life and I doubt whether the attention of surgeons was ever fully awakened to the possibility of reducing the mortality of great operations before Sir James Paget, at the meeting of the British Medical Association in London, in 1862, delivered his memorable address upon the study of the large group of diseases confounded under the name of "pyiemia."

'T'wo years afterwards, at Cambridge, I addressed the Association upon the same subject; and, after alluding to many sanitary measures, called attention to the bearing of the then recent rcsearches of Davaine and Pasteur, and to the value of Polli's experiments upon the use of sulphurous acid and the alkaline and earthy sulphites in the preven. tion and treatment of many of the infectious and contegious causes of excessive mortality after operations. We were on the dawn of that phase of modern surgery, when the so-called laws of sanitary science were tested in the laboratory by physiological chemistry and experimental pathology, and wcre afterwards acted on by Lister and his followers.

During this time of reaction and activity in abdominal surgery, there was a corresponding development of the literature of the subject. It appeared in all shapes, and came from all quarters. The names of men who have since become celebrated were ushered in with their first contributions. Essays and records of cases abounded in periodicals. Pamphlets fell thick upon the public, and books were published which, though more or less incomplete, showed how fast material was accumulating for the future composition of elaborate treatises.

A reviow of all this matter poured out by the press, both English and foreign, on the question of ovariotomy, a few years before and after the date of 1865 , enables us in a measure to gauge the extent of the interest the opcration had excited, the change of opinion in reference to it, the success that had attended it, and to trace the indi. cations which the reports contained of the spreading eagerness of the profession to seize every opportunity of giving to humanity the benefits which the practice was capable of conferring. But that which most forcibly strikes the attention in reading this literature, is the contrast furnished by its toue and tendency with that which preceded and made way for the revival. Previously, all that had been written was sceptical, doubting, speculative, or even prohibitory. Wavering expectation was modest in its demands, timid in its forecastings. There was more of fear than hope for the future. That future came, and with it the revival. Then, instead of the vague prophetic inspirations of the Hunters, the moving exhortations of Bell, the qualified and cautious encouragements of Blundell, the passive admissions of Astley Cooper that ovariotomy might be done-the conscientious shrinking, in au exalted reverence for the sanctity of human life, from the reali- 
sation of what seemed so desirable, and within the compass of dating power-the pathetic wailings over sufferings unrelieved and deaths unresisted, and the despondency of professional inaction-we had reports of accomplishment which proved; by the wideness of their sources, their numerical importance, and the character of their authors, that the revival was assured. The question now changed from one of possibility to one of improvement, and reports of cases merged into discussions of practical details of operative and therapeutical interest. These, from their precautionary or conservative bearing, gave good augury of the vast ameliorations which we have seen within the last twenty years, and have brought us at the present time to nearly certain success, when a careful surgeon operates in a favourable case. One may truly affirm that; in all these outpourings of the revival period, there was nothing vainglorious, boasting, presumptuous. As contributions to science, they were serious, candid, plain, aiding further progress, informing to the profession, and useful to mankind. They bore upon them the signs of a wise resolntion to advance circumspectly upon the path now open; and, if tinged with a glow of the 'personal satisfaction which flows from a sense of duty in part fulfilled, and brightened with a gleam of the complacency reflected from the visible evidence, now so constantly before the public, in the living, healthy survivors of the operation, that the profession as a corporate fraternity was equalling in its philanthropic energy that which had made the reputation and had been the pride and solace of its older s"men of renown," I can only say, not that it was excusable or ad: missible, but that this gratulation was no more than the circumstances prompted, or than may justly be felt by all who join in working, with a right mind and to a good issue, for the welfare of their fellow. creatures.

And here, with 1865, I may end this retrospect of the revival of ovariotomy - of a rapid revolution in opinion and practice in less than ten years. Before 1858, the operation, like all good things, had been of slow growth. One hundred years ago, it was but a germ that might be descried in a lecture by John Hunter. Ten years later, it was seed that fell from the hand of Bell. In little more than another decade, it germinated as a living vitalising reality in Kentucky. Sixty years ago, it was transplanted to the land of its philosophical conception. In twenty years more, we find it a sapling on English soilgrowing slowly at first, and up to 1858 looking as if it might prove no more than a withering gourd. But by 1865 , its root had struck firm, its stem stood erect, its branches were wide and strong, known and sought as a refuge by the sick and dying. That it was no withering gourd has been proved by all that the world has since seen. Thousands of perisning women have been rescued from death; many more thousands of years of human life, health, enjoyment; and usefulness have been given to the race; and to all future victims of a malady before inevitable in its fatality, it gives consolation, hope, and almost certainty of cure.

And passing over another twenty years-advancing from 1865 to 1884-we can rejoice that, in all our metropolitan and most of our provincial hospitals, and from the best teachers on both sides of the Atlantic, medical students of to-day may hear of the good already done-may see for themselves how success is attained; and possibly, by the establishment of some new fact, or the discovery of some new device, they may increase our power over disease, and carry on the work to our successors.

I must leave it to others to speak of our great hospitals and important schools. But I cannot close this part of my address without one word of hearty congratulation to my successors at the small hospital where, with seldom more than six or eight beds at my disposal, in twenty years I completed 408 cases of ovariotomy; the deaths having diminished in successive periods of five years from 1 in 3 to 1 in 4 or 5 , and in the last two years to 1 in 10 . In seven years, 1878-83, my three successors among them had 496 cases-about ninety more than I did alone in twenty years-the deaths falling from 1 in 5 in 1878 to 1 in 18 in 1883. And the recent publication of my colleague Mr. Doran a.dds to the satisfaction I feel in seeing my operative work so efficiently continued, the pleasure of noting how happily he is supplementing the opening of his career as an operator by the intellectually higher distinction of being acknowledged as a penetrating investigator and clear expositor of the obscure subject of ovarian pathology, to which he is devoting his philosophical earnestness. On this centenary of Hunter's lecture, we may truly claim that his example is followed, his foresight verified, and our exertions rewarded.

(To be continued.)

Medical Magistrate.-Dr. William Irving, of Blackburn, has placed on the Commission of the Peace for the County of Lancaster.

\section{AN ADDRESS
THE RELATIONS OF THE MEDICAL PROFESSION. \\ Delivered before the South Wales and Monmouthshire Branch. \\ BY ALFRED SHEEN, M. D., \\ - Senior Surgeon to the Inflrmary, Cardiff, President of the Branch.}

OUR Relations with the Poblic.-These relations are not by any means satisfactory. Our profession is, by not a small number of people, looked down upon and sneered at ; there can be no doubt about that. It is called a noble profession, and it is so ; but its nobility is, I fear, sadly marred by some of its members, found in the highest as well as in the lowest walks of professional life.

Our profession has a twofold character. It is a mission as well as a means of gaining a livelihood. Some of our members, unfortunately, look at it, and practise it, only in the latter aspect. This is what Professor Gairdner, of Glasgow, says of professional men in whom the mercenary feeling predominates : "The physician who is so greedy of emolument that he cannot be downright and sincere, cannot divest himself of the habit of speaking smooth speeches without reality, and practising small devices without meaning ; who now pursues a fashionable line of practice without conviction, and now abandons a real conviction because it is unfashionable, ceases thereby to be a physician, and becomes a quack. His advice will then no longer be the best advice he can give, but the advice which he thinks will answer by flattering the prejudices or administering to the depraved appetites of his patients or society." (" On Money Getting," Lancet, vol. i, 1868, p. 335.)

There was an amusing picture last March, in Punch, of one kind of character in our profession, not uncommon, which no doubt most of you will remember. It represents the drawing-room at a winter healthresort, and one lady says to another, "Oh, that's your doctor, is it? What sort of $a$ doctor is he ?"- "Oh, well, I don't know much about his ability ; but he's got a very good bed-side manner !" The man who drew that picture, drew it from life.

We are very hard upon quacks, and rightly so, but the biggest and worst kind of quacks are those in the profession; and there are plenty of them; and the public is shrewd enough to see this, and to make the most of it-to the detriment of the profession-although blind enough to run with the crowd after the popular professional quacks of the day. Amongst the rarieties of treatment, we have "disease-treating," "case-treating," and "patient-treating." This latter variety is specially contemptible ; it is practised simply to inspire confidence which shall outlive disaster:-Never mind the disease. "It is the bane of the highest social grades of practice, and the blighting evil of all. The charlatan is a treater of patients pure and simple.".... "There is a growing tendency to, and a daily increasing evil of, mannerisms and methods in our profession." (Lancet, vol. ii, 1876, p. 830.) Not a very long time ago a friend of mine consulted a celebrated physician, who, in the course of investigating his case, told him that he (the physician) had the largest practice in the world; something like the Daily Telegraph, with its well known advertisement, "the largest circulation in the world!"

" A single purpose, high views, robust self-respect," will save us from falling into many objectionable peculiarities of character, peculiarities at which shrewd and sensible people only smile. Mr. Tom Hughes offers some sensible advice to medical men. He says "learn to read character by studying your own, to speak plainly, to practise reticence, and to avoid mercenary habits." Again-

$$
\text { "To thine own self be true, }
$$

And it must follow, as the night the day,

Thou canst not then be false to any man."

Our first and chief duty to a patient, when he comes before us, I conceive to be this : honestly and thoroughly to investigate his case, with the sole view of relieving him to the best of our ability; and if, during the progress of the case, we are not quite sure of our own resources, to seek, in consultation, the aid of a colleague in whom we have confidence: It may be that an over-anxious patient will himself suggest a consultation, when we see no need for it ; in such a case, I hold it to be onr duty to accede to his wishes with a good grace. I 